\section{Effect of Postharvest Chemical Treatments, Heat Curing, and Refrigerated Storage on Marketability of Short-day Onions}

\author{
Manish K. Bansal ${ }^{1,3}$, George E. Boyhan ${ }^{1,4,6}$, and \\ Daniel D. MacLean ${ }^{2,5}$
}

ADDITIONAL INDEX WORDs. spring onions, nonstorage onions, Vidalia onions, botrytis neck rot, Botrytis allii, Allium cepa, sour skin, Pseudomonas cepacia

Summary. Vidalia onions (Allium cepa) are very susceptible to infection from pathogens and diseases compared with other types of onions. Botrytis neck rot (BNR) (Botrytis allii) is the most common and destructive storage disease, whereas sour skin (Pseudomonas cepacia) can cause significant bacterial losses, particularly, for late season cultivars. The objective of this study was to assess the effects of different fungicide and bactericide drenches on marketability of Vidalia onions using the cultivar Savannah Sweet grown, harvested, and graded for high-quality onions. Six different fungicide treatments were evaluated, including fludioxonil at two different rates, fluopyram and pyrimethanil in combination, and pyraclostrobin and boscalid in combination with a water-only and an untreated entry. In addition, four different bactericide treatments were evaluated, including copper hydroxide and copper sulfate pentahydrate with a water-only and untreated control. Treatments were applied by drenching the onion bags with 1 gal of solution at the desired concentration. Onions treated with fungicide were inoculated with the pathogen that causes BNR, whereas the bactericide treatments were inoculated with the pathogen that causes sour skin by placing a single inoculated bulb into each bag. Half of the bags were heat-cured for 48 hours and all of the onions were stored immediately under refrigerated conditions at 34 to $36^{\circ} \mathrm{F}$ for 2 or 4 months. Bactericide treatments were not heat-cured the second year of the study. Onions were evaluated after 1 and 14 days of shelf life. For both years, all the fungicide applications were effective with more marketable onions compared with the controls. Fludioxonil, fluopyram/pyrimethanil, and boscalid/pyraclostrobin had the highest percentage of marketable onions compared with the water or untreated controls. Fluopyram/pyrimethanil and boscalid/pyraclostrobin fungicides had significantly higher percentage of marketable onions than the controls but were similar to the low rate of fludioxonil. Bactericide applications were not effective in reducing losses when compared with the controls.

$\mathrm{W}$ orldwide, the United States ranks third in the production of dry bulb onions after China and India, with production at 3.2 million tonnes with a value of $\$ 950$ million in 2014 (FAO, 2017). The Vidalia onion industry is an important component of Georgia's agriculture and economy. In 2014, more than 12,000 acres were harvested in Georgia with an estimated farm gate value of $\$ 138$ million (Wolfe and Stubbs, 2015). In

${ }^{1}$ Department of Horticulture, University of Georgia, 1111 Miller Plant Science Building, Athens, GA 30602

${ }^{2}$ Department of Horticulture, University of Georgia, 4604 Research Way, Tifton, GA 31794

${ }^{3}$ Former Graduate Student.

${ }^{4}$ Professor and Extension Vegetable Specialist.

${ }^{5}$ Former Assistant Professor and currently New Business Development Research Manager, AgroFresh.

${ }^{6}$ Corresponding author. E-mail: gboyhan@uga.edu.

https://doi.org/10.21273/HORTTECH03903-17 terms of revenue generated among vegetables, onions ranked first in Georgia with $13.6 \%$ of total vegetable farm gate value in the state (Wolfe and Stubbs, 2015). Vidalia onions are short-day onions that bulb when day lengths reach $11-12 \mathrm{~h}$ during late winter and early spring. Short-day onions are also noted for having high water content and low solids, including sulfur, that make them both mild flavored and more susceptible to diseases (Boyhan and Torrance, 2002; Maw et al., 1997b).

Several fungal and bacterial pathogens can attack Vidalia onions and can cause such diseases as BNR, purple blotch (Alternaria porri), pink root (Phoma terrestris), and stemphylium leaf blight (Stemphylium vesicarium) all of which can cause severe damage to the crop. Of all of the diseases, BNR is the most important in postharvest-stored onions. In some years, $70 \%$ of the total stored crop can be damaged by the pathogen that causes BNR (Sanders et al., 2008). Under favorable conditions, this pathogen invades the dead or dying tissue of the onion bulb, and then it grows downward through the neck into the bulbs (Pappelis et al., 1974).

Postharvest diseases may start before or after harvest. A number of postharvest diseases such as gray mold (Botrytis cinerea) of grape (Vitus sp.), brown rot (Monilinia fructicola) of peach (Prunus persica), and yeasty rot (Geotrichum candidum) of tomato (Solanum lycopersicum) infect the crop in the field shortly before harvest. However, symptoms of these diseases might not be visible in the field, but symptoms may become visible when the pathogen grows under storage conditions. Preand postharvest applications of labeled fungicides are used to control these diseases (Coates and Johnson, 1997). Postharvest application of fungicides can inhibit fungal activity of a number of microorganisms, which results in improved shelf life of amla or indian gooseberry [Phyllanthus emblica (Ram et al., 2011)]. Presently, few postharvest "reduced risk" fungicides, as designated by the U.S. Environmental Protection Agency (EPA), have been registered for horticultural crops in the United States (Schirra et al., 2011).

Fludioxonil (Syngenta, Greensboro, NC) is one of the fungicides registered for postharvest treatment of various diseases and is marketed as Scholar. The active ingredient belongs

\begin{tabular}{llll}
\hline $\begin{array}{l}\text { Units } \\
\begin{array}{l}\text { To convert U.S. to SI, } \\
\text { multiply by }\end{array}\end{array}$ & U.S. unit & SI unit & $\begin{array}{l}\text { To convert SI to U.S., } \\
\text { multiply by }\end{array}$ \\
\hline 0.4047 & acre $(\mathrm{s})$ & $\mathrm{ha}$ & 2.4711 \\
7.8125 & $\mathrm{fl} \mathrm{oz} / \mathrm{gal}$ & $\mathrm{mL} \cdot \mathrm{L}^{-1}$ & 0.1280 \\
0.0283 & $\mathrm{ft}^{3}$ & $\mathrm{~m}^{3}$ & 35.3147 \\
3.7854 & gal & $\mathrm{L}$ & 0.2642 \\
2.54 & inch(es) & $\mathrm{cm}$ & 0.3937 \\
0.001 & $\mathrm{ppm}$ & $\mathrm{g} \cdot \mathrm{L}^{-1}$ & 1,000 \\
0.9072 & ton $(\mathrm{s})$ & tonne $(\mathrm{s})$ & 1.1023 \\
$\left({ }^{\circ} \mathrm{F}-32\right) \div 1.8$ & ${ }^{\circ} \mathrm{F}$ & ${ }^{\circ} \mathrm{C}$ & $\left({ }^{\circ} \mathrm{C} \times 1.8\right)+32$ \\
& & &
\end{tabular}


to the phenylpyrrole family. Fludioxonil is classified by the EPA as a "reduced risk" fungicide (Fenoll et al., 2009). According to the Fungicide Resistance Action Committee (FRAC) classification based on the mode of action, it is classified as a group 12 fungicide, which are involved in disrupting signal transduction (Rosenberger, 2009). It has a wide spectrum of activity and is registered for postharvest use on stone fruit (Prunus sp.), apple (Malus domestica), pear (Pyrus communis), kiwifruit (Actinidia deliciosa), yam (Diosorea sp.), and others (Tedford, 2004). It is not currently labeled for use on onion. It is a nonsystemic fungicide, which inhibits the cell growth of fungi by inhibiting osmotic signal transduction (Fenoll et al., 2009). Because of its long residual and ability to inhibit sporulation of targeted pathogens, it helps to enable fruit storage for longer periods without spreading diseases in the packinghouse or during shipment. Its unique mode of action makes it effective in disease control even against the fungal isolates that are resistant to other fungicides (Tedford, 2004).

Fluopyram/pyrimethanil (Bayer CropScience, Research Triangle Park, $\mathrm{NC)}$ is a broad-spectrum fungicide combination that is sold as Luna Tranquility (Bayer CropScience, 2016). It is classified as a group 7/9 fungicide according to the FRAC codes. Fluopyram/pyrimethanil is a succinate dehydrogenase inhibitor that is labeled for preharvest use on onions. It should not be applied within $7 \mathrm{~d}$ of harvest for onions.

Boscalid/pyraclostrobin (BASF, Research Triangle Park, NC) is a preharvest fungicide marketed in a formulation as Pristine and used to control different fungal diseases in various crops, including onions (BASF Corporation, 2017). Boscalid is a new broad-spectrum fungicide belonging to the carboxamide class and pyraclostrobin belongs to the quinine outside inhibitor class (Xiao and Boal, 2009). These fungicides have different modes of action, but they both inhibit respiration (Kim and Xiao, 2010). Boscalid/pyraclostrobin should not be applied within 7 $\mathrm{d}$ of harvest.

Copper-based materials have broad effectiveness against a number of pathogens. Copper hydroxide (Griffin, Valdosta, GA) is a chemical compound marketed as Kocide, which acts both as a fungicide and bactericide, and is labeled for use on onions. It is used as a preharvest fungicide to prevent diseases in a number of fruits and vegetables. Copper hydroxide converts into ionic copper as the active ingredient and can be used up until the day of harvest (DuPont, 2009). The mode of action of copper-based compounds is an $\mathrm{M}$ according to the FRAC classification with multisite contact activity (Horton, 2016). They can denature proteins and enzymes (Babadoost, 2012). They prevent diseases as a nonsystemic protectant (Petit et al., 2012). Copper sulfate pentahydrate (Quadrual, Ridgefield, CT) is another copper-based compound marketed as ClearBlue 104, which is used to suppress microorganisms. It is also effective against algae, fungi, and bacteria (Quadrual, 2011).

Another important postharvest treatment required for long-term storage of onion bulbs is curing (Maw et al., 1997a). Curing is a drying process intended to dry down the necks (Bayat et al., 2010) and outer scales of the bulbs (Maw et al., 2004) to prevent the loss of moisture and attack by pathogenic organisms during storage. From harvest to storage, curing can occur at any stage, whenever the conditions around the bulb become favorable to remove moisture from the bulb (Maw et al., 2004).

There are two ways of curing onion bulbs: artificial and natural. Natural curing takes place under the sun and wind after the harvest when bulbs are left in the field. It is the least expensive way of curing and can be helpful in enhancing onion quality by allowing downward movement of nutrients from tops into the bulb (Maw et al., 1997a). Drying onions by forcing heated air around the bulbs is another way of curing. Standard conditions for this type of curing are blowing the dry, hot (up to $100{ }^{\circ} \mathrm{F}$ ) air around the onions with an airflow of $365-1030 \mathrm{ft}^{3} / \mathrm{min}$ per ton of onions (Boyhan et al., 2001). The duration of heat curing varies according to the harvest maturity of the bulbs. For early harvested onions, longer curing is required than for those harvested at the optimal time. Early harvested onions benefit from heat curing of $72 \mathrm{~h}$, whereas optimally mature onions require only 48 h (Maw et al., 1997b).
The objectives of this study were to evaluate postharvest treatments, time in storage, and poststorage shelf life on marketability of Vidalia onions.

\section{Materials and methods}

This 2-year study evaluated postharvest treatments, time in storage, and poststorage shelf life. In the first year, the cultivar Savannah Sweet was grown according to recommendations of the Georgia Cooperative Extension Service (Boyhan et al., 2001) at the Vidalia Onion and Vegetable Research Center in Lyons, GA (lat. $32^{\circ} 11^{\prime} \mathrm{N}$, long. $82^{\circ} 17^{\prime} \mathrm{W}$ ). Harvesting at optimal maturity began with undercutting on 10 May 2010 and 21 Apr. 2011. Optimal maturity is defined when $20 \%$ to $50 \%$ of the tops are broken over at the neck or there is significant weakness in the neck and the bulbs have reached an appropriate size (majority $\geq 3$ inches) for harvest. After harvest, bulbs were transported to the Vidalia Onion Research Laboratory (VORL) in Tifton, GA. On the same day, the bulbs arrived at the VORL; they were cleaned, sorted, and graded manually to choose visually marketable onions (i.e., appropriate Vidalia onion shape, free of defects, diseases, and damage) of good size ( $\geq 3$ inches) for the study. Bulbs were segregated into 20-bulb lots and placed into polypropylene mesh bags to insure good air circulation. Onions were handled in a similar fashion both years.

Eight treatments, including fungicides and a bactericide, were used in the study. Rates chosen reflect recommended label rates. In 2010, the fungicides used were 1) fluopyram and pyrimethanil at 0.15 and 0.44 $\mathrm{mL} \cdot \mathrm{L}^{-1}$, respectively, 2 ) boscalid and pyraclostrobin at 9.0 and $4.6 \mathrm{~mL} \cdot \mathrm{L}^{-1}$, respectively, and 3 ) fludioxonil at two rates 6.3 and $12.7 \mathrm{~mL} \cdot \mathrm{L}^{-1}$. Also included were a water-only and an untreated control. The bactericide evaluated was copper hydroxide at $0.55 \mathrm{~g} \cdot \mathrm{L}^{-1}$. In 2011 , one more bactericide treatment, copper sulfate pentahydrate at $0.59 \mathrm{~mL} \cdot \mathrm{L}^{-1}$, was added to the experiment. The by-year interactions in the analysis did not include copper sulfate pentahydrate.

To apply the treatments, solutions of the desired concentration were made with tap water. Then, the 20 -bulb bags were placed into a 32 -gal polyethylene container (Rubbermaid, 
Huntersville, NC) and 1 gal of the drench solution was poured twice over the onion bulbs (bags were turned over between applications) to insure complete coverage of all sample onions. Immediately after treatment application, a single bulb inoculated with $\mathrm{BNR}$ (obtained from the research farm and validated in the University of Georgia Plant Pathology Laboratory, Tifton, GA) was placed into each bag of onions (including controls) and the bags were turned over a couple of times to insure a random location for the inoculated bulb. Bulbs were inoculated with the pathogen by coating a nail with the pathogen and piercing the bulb in several places to transfer the pathogen. In the same manner, after application of the bactericides, a single bulb inoculated with sour skin (obtained from the research farm and validated in the University of Georgia Plant Pathology Laboratory) was placed into the bags before curing or storage. After drenching, half of the treated bags were transported to the Black Shank Farm in Tifton, GA, where they were placed inside a peanut drier for heat curing $\left(99^{\circ} \mathrm{F}\right)$ by forced air for $48 \mathrm{~h}$. The remainder of the bags were maintained inside the VORL facility [ambient conditions: $\approx 75^{\circ} \mathrm{F}$, $\approx 80 \%$ relative humidity $(\mathrm{RH})]$ without heat treatment, were allowed to dry, and were then placed into refrigerated storage at a temperature of 34 to $36^{\circ} \mathrm{F}$ and $\geq 80 \% \mathrm{RH}$. After $48 \mathrm{~h}$, the heat-cured bulbs were removed from the peanut dryer and transported to the VORL where they were placed in refrigerated storage $\left(34\right.$ to $36^{\circ} \mathrm{F}$ and $\geq 80 \% \mathrm{RH}$ ) with the uncured onions.

Bulb samples were removed after 2 and 4 months of storage and warmed to room temperature $\left(\approx 72^{\circ} \mathrm{F}\right)$ under controlled conditions where temperatures were gradually raised in the refrigerated chamber to reduce condensation. The following day, four bags of each treatment were removed randomly and weighed, whereas a similar set of four bags were maintained at room temperature for $14 \mathrm{~d}$ to simulate market conditions, before evaluation.

At each evaluation, all bulbs in each treatment bag were evaluated for infections with BNR, sour skin, slippery skin (Burkholderia gladioli pv. alliicola), physical damage, shriveled, and other storage defects of unknown origin. First, bulbs were evaluated visually for any significant damage or symptoms of diseases. Bulbs were then cut longitudinally to check for internal symptoms of disease. Only the bulbs passing both external and internal examinations were considered marketable. Bulbs kept for $14 \mathrm{~d}$ under ambient conditions $\left(\approx 75^{\circ} \mathrm{F}\right.$, $\approx 80 \% \mathrm{RH}$ ) were evaluated in an identical manner as described previously. These same procedures were used to evaluate onions stored for 4 months.

The experimental design was completely random with an incomplete factorial treatment arrangement. The factorial arrangement was incomplete because copper sulfate pentahydrate was used only in 2011 and there was no heat curing of sour skin-inoculated onions in 2011. There were four replications for each combination of factors. Analysis was carried out separately for the fungicide and bactericide treatments. Data were collected as percent marketable onions. Analysis of variance was performed with Stata 14.1 (StataCorp, College Station, TX). Fisher's protected least significant difference at $P \leq 0.05$ was then calculated.

\section{Results and discussion}

Of the unmarketable onions across all treatments, six different categories and their percentage of occurrence were noted, which included infection with BNR (69\%), sour skin $(3 \%)$, slippery skin $(5 \%)$, physical damage $(3 \%)$, shriveled $(<1 \%)$, and unknown cause (18\%). There was no by-year interaction with the fungicide treatments, so results were combined and examined for both years (Table 1 ). Treatments and evaluation time (day 1 or 14) had significant effects on onion marketability. There were also several significant interactions, including treatment $\times$ curing, treatment $\times$ evaluation time, storage time $\times$ evaluation time, treatment $\times$ storage time $\times$ evaluation time, treatment $x$ curing $x$ evaluation time, and treatment $\times$ storage time $\times$ curing $\times$ evaluation time (Table 1 ).

Fludioxonil at the highest rate with heat curing and after 2 months of storage resulted in more marketable onions than boscalid/pyrimethanil or the untreated control (Table 2). It did not differ from fluopyram/pyrimethanil, fludioxonil at the low rate, or water. Without heat curing after 2 months of storage, fludioxonil at the high rate had more marketable onions compared with the water or untreated controls. However, this did not differ from any of the other fungicide treatments. After 4 months of storage with heat curing, fludioxonil at the high rate resulted in the most marketable onions compared

Table 1. Main effects and interactions of fungicide drench, heat curing, months in cold storage, and evaluation time on marketability of short-day 'Savannah Sweet' onions.

\begin{tabular}{lc}
\hline & Probability \\
\hline Treatment $^{\mathrm{z}}$ & 0.000 \\
Year & 0.487 \\
Treatment $\times$ year & 0.882 \\
Heat curing & 0.198 \\
Storage time $^{\mathrm{x}}$ & 0.076 \\
Evaluation time $^{\mathrm{w}}$ & 0.000 \\
Treatment $\times$ month & 0.766 \\
Treatment $\times$ curing & 0.000 \\
Storage $\times$ curing & 0.199 \\
Treatment $\times$ storage $\times$ curing & 0.182 \\
Treatment $\times$ evaluation time & 0.000 \\
Storage $\times$ evaluation time & 0.000 \\
Treatment $\times$ storage $\times$ evaluation time & 0.022 \\
Curing $\times$ evaluation time & 0.454 \\
Treatment $\times$ curing $\times$ evaluation time & 0.049 \\
Storage $\times$ curing $\times$ evaluation time & 0.383 \\
Treatment $\times$ storage $\times$ curing $\times$ evaluation time & 0.004 \\
\hline
\end{tabular}

${ }^{\mathrm{z}}$ Onions were drenched with the respective treatment fungicide and inoculated with botrytis neck rot before refrigerated storage.

${ }^{\mathrm{y}}$ Heat curing $=$ artificially drying onions with forced air at $99^{\circ} \mathrm{F}\left(37.2^{\circ} \mathrm{C}\right)$ for $48 \mathrm{~h}$ after tops and roots have been removed; no heat curing $=$ tops and roots are only removed

${ }^{\mathrm{x}}$ Refrigerated [ 33 to $35^{\circ} \mathrm{F}\left(0.6\right.$ to $\left.1.7^{\circ} \mathrm{C}\right), 70 \%$ relative humidity $(\mathrm{RH})$ ] storage for 2 or 4 months.

${ }^{\mathrm{w}}$ Onions evaluated immediately on removal from refrigerated storage or $14 \mathrm{~d}$ later under ambient conditions $\left[\approx 75^{\circ} \mathrm{F}\left(23.9^{\circ} \mathrm{C}\right), \approx 80 \% \mathrm{RH}\right]$ 
with fluopyram/pyrimethanil, boscalid/ pyraclostrobin, water, or the untreated controls. Fludioxonil at the high rate after 4 months of storage and heat curing did not, however, differ from the fludioxonil at the low-rate treatment. Finally, without heat curing after 4 months of storage, the fluopyram/pyrimethanil treatment did better than fludioxonil, water, or untreated controls but did not differ from fludioxonil at the high rate, or the boscalid/pyrclostrobin treatment.

There were no differences between treatments after 2 months of storage immediately after removal (Table 3). After 2 months of storage, onions evaluated $14 \mathrm{~d}$ after removal had the greatest percent marketable onions with fludioxonil at the highest rate. This was significantly better than boscalid/pyraclostrobin, water, or the untreated controls, but not different from fludioxonil at the low rate or fluopyram/pyrimethanil. Fourteen days after removal from storage, all fungicide treatments had more marketable onions than the untreated or water checks (Table 3 ). Fludioxonil at the high rate was better than the water or untreated controls immediately after removal from 4 months of storage (Table 3). However, the high rate of fludioxonil did not differ from the low rate of fludioxonil, fluopyram/ pyrimethanil, or boscalid/pyraclostrobin treatment. Fourteen days after removal from 4 months of storage, all of the fungicide treatments were significantly better than the water or untreated controls.

The storage time by curing interaction indicated no significant differences between curing or time in storage for percent marketable onions (data not shown). The significant four-way interaction did not elucidate the results any further than the two-way or threeway interaction (data not shown).

There was no by-year interaction for the bactericide treatments, so the results are presented for both years (Table 4). Treatments, curing, and evaluation time ( 1 or $14 \mathrm{~d}$ after storage removal) were significant. There were several interactions with the bactericide treatments, including storage time $x$ curing, treatment $\times$ storage time $\times$ curing, treatment $\times$ evaluation time, storage $\times$ evaluation time, and curing $\times$ evaluation time.

Heat-cured onions did not show significant differences from uncured

Table 2. Interaction effects of fungicide drench on percent marketability of short-day 'Savannah Sweet' onions with and without heat curing after 2 or 4 months in refrigerated storage combined for 2 years.

\begin{tabular}{|c|c|c|c|c|}
\hline \multirow[b]{3}{*}{ Treatment $^{\mathrm{z}}$} & \multicolumn{4}{|c|}{ Marketable (\%) } \\
\hline & \multicolumn{2}{|c|}{2 mo. $^{y}$} & \multicolumn{2}{|c|}{$4 \mathrm{mo}}$. \\
\hline & Heat curing & $\begin{array}{l}\text { No heat } \\
\text { curing }\end{array}$ & Heat curing & $\begin{array}{l}\text { No heat } \\
\text { curing }\end{array}$ \\
\hline Fludioxonil $\left(12.7 \mathrm{~mL} \cdot \mathrm{L}^{-1}\right)$ & $85 \mathrm{a}^{\mathrm{x}}$ & 85 a & $85 a$ & $80 \mathrm{ab}$ \\
\hline $\begin{array}{l}\text { Fluopyram and pyrimethanil } \\
\left(0.15 \text { and } 0.44 \mathrm{~mL} \cdot \mathrm{L}^{-1}\right)\end{array}$ & $78 \mathrm{ab}$ & $83 \mathrm{a}$ & $72 \mathrm{bc}$ & 86 a \\
\hline Water & $76 \mathrm{ab}$ & $60 \mathrm{~b}$ & $70 \mathrm{~cd}$ & $55 \mathrm{c}$ \\
\hline Fludioxonil $\left(6.3 \mathrm{~mL} \cdot \mathrm{L}^{-1}\right)$ & $76 \mathrm{ab}$ & $81 \mathrm{a}$ & $80 \mathrm{ab}$ & $73 \mathrm{~b}$ \\
\hline $\begin{array}{l}\text { Boscalid and pyraclostrobin } \\
\quad\left(9.0 \text { and } 4.6 \mathrm{~mL} \cdot \mathrm{L}^{-1}\right)\end{array}$ & $68 c$ & 81 a & $70 \mathrm{~cd}$ & $79 \mathrm{ab}$ \\
\hline Untreated & $61 \mathrm{c}$ & $55 \mathrm{~b}$ & $61 \mathrm{~d}$ & $41 \mathrm{~d}$ \\
\hline
\end{tabular}

${ }^{\mathrm{z}} \mathrm{l} \mathrm{mL} \cdot \mathrm{L}^{-1}=0.1280 \mathrm{fl} \mathrm{oz} / \mathrm{gal}$.

${ }^{\mathrm{y}}$ Refrigerated [ 33 to $35{ }^{\circ} \mathrm{F}\left(0.6\right.$ to $\left.1.7^{\circ} \mathrm{C}\right), 70 \%$ relative humidity] storage for 2 or 4 months; heat curing = artificially drying onions with forced air at $99^{\circ} \mathrm{F}\left(37.2^{\circ} \mathrm{C}\right)$ for $48 \mathrm{~h}$ after tops and roots have been removed; no heat curing $=$ tops and roots are only removed.

${ }^{\mathrm{x}}$ Means followed by the same letter within a column are not significantly different by Fisher's protected least significant difference $(P \leq 0.05)$

Table 3. Interaction effects of fungicide drench on percent marketability of short-day 'Savannah Sweet' onions after 2 or 4 months in refrigerated storage evaluated 1 or $14 \mathrm{~d}$ after removal from storage combined for 2 years.

\begin{tabular}{|c|c|c|c|c|}
\hline \multirow[b]{5}{*}{ Treatment $^{\mathrm{z}}$} & \multicolumn{4}{|c|}{ Storage time $(\text { mo. })^{\mathrm{y}}$} \\
\hline & \multicolumn{2}{|c|}{2} & \multicolumn{2}{|c|}{4} \\
\hline & \multicolumn{4}{|c|}{ Time after removal from storage $(\mathrm{d})^{\mathrm{x}}$} \\
\hline & 1 & 14 & 1 & 14 \\
\hline & \multicolumn{4}{|c|}{ Marketable (\%) } \\
\hline Fludioxonil $\left(12.7 \mathrm{~mL} \cdot \mathrm{L}^{-1}\right)$ & 90 & $80 \mathrm{a}^{\mathrm{w}}$ & $86 \mathrm{a}$ & $80 \mathrm{a}$ \\
\hline Fludioxonil $\left(6.3 \mathrm{~mL} \cdot \mathrm{L}^{-1}\right)$ & 84 & $73 \mathrm{ab}$ & $78 \mathrm{ab}$ & $75 \mathrm{a}$ \\
\hline $\begin{array}{c}\text { Fluopyram and pyrimethanil } \\
\left(0.15 \text { and } 0.44 \mathrm{~mL} \cdot \mathrm{L}^{-1}\right)\end{array}$ & 88 & $72 \mathrm{ab}$ & $82 \mathrm{ab}$ & $78 \mathrm{a}$ \\
\hline $\begin{array}{l}\text { Boscalid and pyraclostrobin } \\
\left(9.0 \text { and } 4.6 \mathrm{~mL} \cdot \mathrm{L}^{-1}\right)\end{array}$ & 86 & $63 \mathrm{~b}$ & $79 \mathrm{ab}$ & $71 \mathrm{a}$ \\
\hline Water & 87 & $49 \mathrm{c}$ & $74 \mathrm{bc}$ & $54 \mathrm{~b}$ \\
\hline Untreated & 87 & $28 \mathrm{~d}$ & $67 \mathrm{c}$ & $40 \mathrm{~b}$ \\
\hline
\end{tabular}

${ }^{\mathrm{z}} 1 \mathrm{~mL} \cdot \mathrm{L}^{-1}=0.1280 \mathrm{fl} \mathrm{oz} / \mathrm{gal}$.

${ }^{\mathrm{y}}$ Refrigerated [ 33 to $35^{\circ} \mathrm{F}\left(0.6\right.$ to $\left.1.7^{\circ} \mathrm{C}\right), 70 \%$ relative humidity (RH)] storage for 2 or 4 months.

${ }^{\mathrm{x}}$ Onions evaluated immediately on removal from refrigerated storage or $14 \mathrm{~d}$ later under ambient conditions $[\approx 75$ $\left.{ }^{\circ} \mathrm{F}\left(23.9^{\circ} \mathrm{C}\right), \approx 80 \% \mathrm{RH}\right]$.

wheans followed by the same letter within a column are not significantly different by Fisher's protected least significant difference $(P \leq 0.05)$.

onions that were stored for 2 months after bactericide treatments (Table 5 ). With 4 months of cold storage, heatcured onions had a greater percentage of marketable onions compared with uncured onions. There was no difference with heat-cured onions between 2 and 4 months of cold storage with bactericide treatments. Without the heat curing, onions stored for 2 months had significantly more marketable onions compared with those stored for 4 months.

There were no differences between the bactericide treatments and controls after 2 months of cold storage whether they were heat-cured or not (Table 6). Onions stored for
4 months with heat curing had the most marketable onions with the water treatment, which did not differ from either the copper sulfate or untreated control. All of these treatments (copper sulfate, water, and untreated) had more marketable onions compared with the copper hydroxide pentahydrate treatment.

There were no differences between bactericide treatments immediately after removal from storage (Table 7). Copper sulfate had the greatest percent marketable onions $14 \mathrm{~d}$ after removal from storage. This was greater than copper hydroxide pentahydrate or the untreated control but did not differ from the water control. 
Table 4. Main effects and interactions of bactericide drench, heat curing, and months in cold storage on marketability of short-day 'Savannah Sweet' onions.

\begin{tabular}{|c|c|}
\hline & Probability \\
\hline Treatment $^{\mathrm{z}}$ & 0.000 \\
\hline Year & 0.000 \\
\hline Treatment $\times$ year & 0.052 \\
\hline Curing $^{\mathrm{y}}$ & 0.021 \\
\hline Storage time $\mathrm{e}^{\mathrm{x}}$ & 0.259 \\
\hline Evaluation time $^{\mathrm{w}}$ & 0.000 \\
\hline Treatment $\times$ storage time & 0.186 \\
\hline Treatment $\times$ cure & 0.072 \\
\hline Storage $\times$ curing & 0.005 \\
\hline Treatment $\times$ storage $\times$ curing & 0.046 \\
\hline Treatment $\times$ evaluation time & 0.010 \\
\hline Storage $\times$ evaluation time & 0.000 \\
\hline Treatment $\times$ storage $\times$ evaluation time & 0.759 \\
\hline Curing $\times$ evaluation time & 0.038 \\
\hline Treatment $\times$ curing $\times$ evaluation time & 0.052 \\
\hline Storage $\times$ curing $\times$ evaluation time & 0.108 \\
\hline Treatment $\times$ storage $\times$ curing $\times$ evaluation time & 0.166 \\
\hline \multicolumn{2}{|c|}{  } \\
\hline
\end{tabular}

Table 5. Interaction effects of curing and storage time for short-day 'Savannah Sweet' onions treated with bactericide drenches combined for 2 years. $^{\mathrm{z}}$

\begin{tabular}{lccc}
\hline & \multicolumn{2}{c}{ Marketable (\%) } & \\
\cline { 2 - 3 } Postharvest curing & 2 mo. $^{\mathbf{x}}$ & $\mathbf{4 ~ m o .}$ & Probability \\
\hline Heat-cured (2010 only) & 59 & 62 & 0.475 \\
No heat curing & 62 & 46 & 0.019 \\
Probabilities & 0.654 & 0.001 & \\
\hline
\end{tabular}

${ }^{7}$ Treatment drenches included copper sulfate $\left(0.59 \mathrm{~mL} \cdot \mathrm{L}^{-1}\right) 2011$ only, copper hydroxide $\left(0.55 \mathrm{~g} \cdot \mathrm{L}^{-1}\right)$, water, and no drench. All treatments were inoculated with sour skin; $1 \mathrm{~mL} \cdot \mathrm{L}^{-1}=0.1280 \mathrm{fl} \mathrm{oz} / \mathrm{gal}, 1 \mathrm{~g} \cdot \mathrm{L}^{-1}=1,000 \mathrm{ppm}$. ${ }^{\mathrm{y}} \mathrm{Heat}$ curing $=$ artificially drying onions with forced air at $99^{\circ} \mathrm{F}\left(37.2^{\circ} \mathrm{C}\right)$ for $48 \mathrm{~h}$ after tops and roots have been removed; no heat curing = tops and roots are only removed.

${ }^{\mathrm{x}}$ Refrigerated [ 33 to $35^{\circ} \mathrm{F}\left(0.6\right.$ to $\left.1.7^{\circ} \mathrm{C}\right), 70 \%$ relative humidity] storage for 2 or 4 months.

Table 6. Interaction effects of bactericide treatment on marketability of sour skin-inoculated short-day 'Savannah Sweet' onions with or without heat curing evaluated after 2 or 4 months in refrigerated storage combined for 2 years.

\begin{tabular}{|c|c|c|c|c|}
\hline \multirow[b]{3}{*}{ Treatments $^{\mathrm{z}}$} & \multicolumn{4}{|c|}{ Marketable (\%) } \\
\hline & \multicolumn{2}{|c|}{2 mo. $^{y}$} & \multicolumn{2}{|c|}{$4 \mathrm{mo}}$. \\
\hline & Heat curing $^{x}$ & No curing & Heat curing & No curing \\
\hline Water & 59 & 64 & $72 \mathrm{a}^{\mathrm{w}}$ & 42 \\
\hline Untreated & 47 & - & $67 \mathrm{a}$ & - \\
\hline $\begin{array}{l}\text { Copper sulfate }\left(0.59 \mathrm{~mL} \cdot \mathrm{L}^{-1}\right) \\
2011 \text { only }\end{array}$ & 67 & 63 & $66 \mathrm{a}$ & 46 \\
\hline Copper hydroxide $\left(0.55 \mathrm{~g} \cdot \mathrm{L}^{-1}\right)$ & 56 & 58 & $47 \mathrm{~b}$ & 50 \\
\hline
\end{tabular}

${ }^{\mathrm{z}}$ Onions were evaluated for marketability after a bactericide drench and inoculation with sour skin with and without heat curing and refrigerated $\left[33\right.$ to $35^{\circ} \mathrm{F}\left(0.6\right.$ to $\left.1.7^{\circ} \mathrm{C}\right), 70 \%$ relative humidity $\left.(\mathrm{RH})\right]$ storage for 2 or 4 months; 1 $\mathrm{mL} \cdot \mathrm{L}^{-1}=0.1280 \mathrm{fl} \mathrm{oz} / \mathrm{gal}, 1 \mathrm{~g} \cdot \mathrm{L}^{-1}=1,000 \mathrm{ppm}$.

${ }^{\mathrm{y}}$ Refrigerated ( 33 to $\left.35^{\circ} \mathrm{F}, 70 \% \mathrm{RH}\right)$ storage for 2 or 4 months.

${ }^{\mathrm{x}}$ Heat curing $=$ artificially drying onions with forced air at $99^{\circ} \mathrm{F}\left(37.2^{\circ} \mathrm{C}\right)$ for $48 \mathrm{~h}$ after tops and roots have been removed. Heat curing was performed in 2010 only. No heat curing = tops and roots are only removed.

weans followed by the same letter within a column are not significantly different by Fisher's protected least significant difference $(P \leq 0.05)$.

Onions with the bactericide treatments stored for 2 months had 85\% marketable onions compared with $62 \%$ marketable after 4 months of storage for onions evaluated immediately after removal from storage (data not shown). Conversely, after $14 \mathrm{~d}$, onions stored for 4 months had more marketable onions with $52 \%$ compared with $34 \%$ for onions stored for 2 months. Whether onions were stored for 2 or 4 months, there were more marketable onions immediately after removal $(85 \%$ and $62 \%$, respectively) compared with onions evaluated 14 d later (34\% and $52 \%$, respectively).

Heat curing compared with no heat curing had no effect on percent marketable onions whether evaluated at 1 or $14 \mathrm{~d}$ after removal from storage. However, there were more marketable onions immediately after removal from storage compared with $14 \mathrm{~d}$ later whether the onions were heat-cured or not.

Using a postharvest drench as in this study is not practiced in the onion industry in Georgia (Boyhan et al., 2001). In fact, there are no fungicides labeled for postharvest use on onions in the United States. However, it does show promise for improving onion storage. Short-day onions are difficult to store because they have high water content and low solids. Typically, under ambient conditions, they have a postharvest shelf life of $\approx 1$ month. This has been extended with the adoption of controlled atmosphere (CA) storage with high carbon dioxide, low oxygen, refrigerated storage (Boyhan et al., 2001). This technology was widely adopted in the late 1980s. However, it has not been as consistent as growers had hoped. Generally, in 1 of every 4 years the percentage of marketable onions from storage is very poor $(\approx 25 \%)$ and infection with BNR is the primary cause. It is known that BNR can continue to grow in CA storage; however, it does not sporulate, so infection is restricted to onions infected before storage or onions immediately adjacent to infected stored onions (Purvis et al., 2001).

Using a prestorage fungicide drench and refrigerated storage in combination may be a viable alternative to CA storage as it would be less expensive and may offer storability comparable to CA. These fungicide treatments in combination with CA storage may also be a viable option in improving the consistency of CA storage. The fungicide treatments appear to be, particularly, helpful where no heat curing is used; however, heat 
Table 7. Interaction effects of bactericide treatment on marketability of shortday 'Savannah Sweet' onions evaluated immediately after removal from cold storage and $14 \mathrm{~d}$ later under ambient conditions combined for 2 years.

\begin{tabular}{lcc}
\hline & \multicolumn{2}{c}{ Marketable (\%) } \\
\cline { 2 - 3 } Treatments $^{\mathrm{z}}$ & Day $\mathbf{1}^{\mathbf{y}}$ & Day 14 \\
\hline Copper sulfate $\left(0.59 \mathrm{~mL} \cdot \mathrm{L}^{-1}\right) 2011$ only & 71 & $54 \mathrm{a}^{\mathrm{x}}$ \\
Water & 77 & $45 \mathrm{ab}$ \\
Copper hydroxide $\left(0.55 \mathrm{~g} \cdot \mathrm{L}^{-1}\right)$ & 70 & $35 \mathrm{~b}$ \\
Untreated & 81 & $33 \mathrm{~b}$ \\
\hline
\end{tabular}

${ }^{\mathrm{z}}$ Onions were evaluated for marketability after a bactericide drench and inoculation with sour skin with and without heat curing and refrigerated [ 33 to $35^{\circ} \mathrm{F}\left(0.6\right.$ to $\left.1.7^{\circ} \mathrm{C}\right), 70 \%$ relative humidity $\left.(\mathrm{RH})\right]$ storage for 2 or 4 months; $1 \mathrm{~mL} \cdot \mathrm{L}^{-1}=0.1280 \mathrm{fl} \mathrm{oz} / \mathrm{gal}, 1 \mathrm{~g} \cdot \mathrm{L}^{-1}=1,000 \mathrm{ppm}$.

${ }^{\mathrm{y}}$ Onions evaluated immediately on removal from refrigerated storage or $14 \mathrm{~d}$ later under ambient conditions $\left[\approx 75^{\circ} \mathrm{F}\left(23.9^{\circ} \mathrm{F}\right), \approx 80 \% \mathrm{RH}\right]$.

${ }^{x}$ Means followed by the same letter within a column are not significantly different by Fisher's protected least significant difference $(P \leq 0.05)$.

curing is a standard practice in onion production and continues to be recommended, so this impact is minimal.

Fludioxonil did well overall in minimizing damage to the onions. Unfortunately, it is not currently labeled for use in onions. It was included because it is specifically labeled to control postharvest diseases in other crops and so was considered a good candidate for testing. Perhaps in the future, a label could be acquired for onions. Fluopyram/pyrimethanil and boscalid/pyraclostrobin both have a 7-d-preharvest restriction of application; however, because these onions were going into long-term storage ( 2 or 4 months), this was not a concern and these products are particularly effective against the target organisms.

There was no clear benefit of the bactericide treatments on onion storability. This is not surprising because BNR is by far the most prevalent disease in postharvest onions. Bacterial diseases generally are of only minor concern in storage.

Rapid decline of onions after removal from storage is a common occurrence (Boyhan et al., 2005). This also occurred in this study with losses ranging from more than $20 \%$ to more than $40 \%$. From a grower's perspective, this is not much of a concern, but to buyers acquiring onions from storage, this can be a significant concern. This can also be a concern to end users who should be cognizant of this problem, particularly, when buying short-day onions out of season.

Heat curing was not included in the second year with the bactericidal experiment because high temperatures are known to accelerate the development of sour skin (Schwartz and Mohan, 2008). It was thought that by excluding heat curing, a better profile of the treatments would be realized.

In conclusion, fungicide drenches postharvest show some promise for disease control and reducing losses of marketable onions after removal from storage. Bactericide drenches, however, do not offer the same level of response compared with the water or untreated controls.

\section{Literature cited}

Babadoost, M. 2012. Protectant vs. systemic fungicides. 28 Nov. 2012. <http:// jhawkins 54 .typepad.com/files/ babadoost-jan-12-understandingchoosing-protectant-versus-systemicfungicides-1.pdf>.

BASF Corporation. 2017. Pristine ${ }^{\circledR}$ fungicide. 9 Jan. 2017. <http://agproducts. basf.us/products/pristine-fungicide. html>.

Bayat, F., S. Rezvani, and A.E. Nosrati. 2010. Effect of harvesting time and curing temperature on some properties of Iranian white garlic. Acta Hort. 877:869875.

Bayer CropScience. 2016. Bayer Luna Tranquility. 20 Jan. 2017. <https://s3us-west-1.amazonaws.com/www.agrian. com/pdfs/Luna_Tranquilityld_Label. $\mathrm{pdf}>$.

Boyhan, G., D. Granberry, and T. Kelley (eds.). 2001. Onion production guide. Univ. Georgia Coop. Ext. Serv. Bul. 1198.

Boyhan, G.E., A.C. Purvis, W.M. Randle, R.L. Torrance, M.J. Cook, G. Hardison, R.H. Blackley, H. Paradice, C.R. Hill, and J.T. Paulk. 2005. Harvest and postharvest quality of short-day onions in variety trials in Georgia, 2000-03. HortTechnology 15:694-706.
Boyhan, G.E. and R.L. Torrance. 2002. Vidalia onions-Sweet onion production in southeastern Georgia. HortTechnology 12:196-202.

Coates, L. and G. Johnson. 1997. Postharvest diseases of fruit and vegetables, p. 533-547. In: J.F. Brown and H.J. Ogle (eds.). Plant pathogens and plant diseases. Rockvale Publ., Berringer, Austrialia.

DuPont. 2009. DuPont Kocide ${ }^{\circledR} 3000$ fungicide/bactericide. 20 Jan. 2017. <http://www.groworganic.com/ media/pdfs/pfm275-b.pdf $>$.

FAO. 2017. FAO statistical databases. 3 Aug. 2017. <http://www.fao.org/ faostat/en/\#data $>$.

Fenoll, J., E. Ruiz, P. Hellín, A. Lacasa, and P. Flores. 2009. Dissipation rates of insecticides and fungicides in peppers grown in greenhouse and under cold storage conditions. Food Chem. 113:727-732.

Horton, D. (ed.). 2016. Georgia pest management handbook. Univ. Georgia Coop. Ext. Serv. Spec. Bul. 28.

Kim, Y.K. and C.L. Xiao. 2010. Resistance to pyraclostrobin and boscalid in populations of Botrytis cinerea from stored apples in Washington state. Plant Dis. 94:604-612.

Maw, B.W., C.L. Butts, A.C. Purvis, K. Seebold, and B.G. Mullinix. 2004. Hightemperature continuous-flow curing of sweet onions. Appl. Eng. Agr. 20:657663.

Maw, B.W., B.G. Mullinix, and D.A. Smittle. 1997a. Artificially curing sweet onions. Appl. Eng. Agr. 13:517-520.

Maw, B.W., B.G. Mullinix, and D.A. Smittle. 1997b. The influence of harvest maturity, curing and storage conditions upon the storability of sweet onions. Appl. Eng. Agr. 13:511-515.

Pappelis, A.J., G.A. Pappelis, and F.B. Kulfinsk. 1974. Nuclear orientation in onion epidermal-cells in relation to wounding and infection. Phytopathology 64:1010-1012.

Petit, A.N., F. Fontaine, P. Vatsa, C. Clément, and N. Vaillant-Gaveau. 2012. Fungicide impacts on photosynthesis in crop plants. Photosyn. Res. 111:315-326.

Purvis, A.C., J.H. Brock, and J.T. Paulk. 2001. Does botrytis spread to sound onions in storage? Georgia Onion 2000 Res. Ext. Rpt. Coop. Res. Ext. Publ. No. 3-2001.

Quadrual. 2011. ClearBlue 104. 2 Aug. 2017. <http://www.kellysolutions.com/ erenewals/documentsubmit/KellyData\% 5CIA $\% 5$ Cpesticide $\% 5$ CProduct $\% 20$ Label \%5C53265\%5C83232-1\%5C83232-1_ 
CLEARBLUE_104_1_26_2009_10_57_ 10_AM.pdf>.

Ram, R.B., M.L. Meena, L. Rubee, and H.H. Yadav. 2011. Effect of post harvest treatments and storage condition on shelf life and quality of aonla cv. NA-6. Prog. Agr. 11:305-310.

Rosenberger, D.A. 2009. Fungicides, biocides, and sanitizers for managing postharvest pathogens in apples. New York Fruit Qrtly. 17(3):3-6.

Sanders, F.H., Jr., D.B. Langston, Jr., and M.J. Foster. 2008. Effect of fungicide dip treatments on fungal diseases and yield of transplanted sweet onions. 2008 Georgia Onion Res. Ext. Rpt. Coop. Res. Ext. Publ. No. 3-2008. Tifton, GA.

Schirra, M., S. D'Aquino, P. Cabras, and A. Angioni. 2011. Control of postharvest diseases of fruit by heat and fungicides: Efficacy, residue levels, and residue persistence. A review. J. Agr. Food Chem. 59:8531-8542.

Schwartz, H.F. and S.K. Mohan. 2008. Compendium of onion and garlic diseases and pests. 2nd ed. Amer. Phytopathological Soc., St. Paul, MN.
Tedford, E.C. 2004. Scholar-A new broad-spectrum postharvest fungicide for pomefruits. 12 Nov. 2012. <http:// postharvest.tfrec.wsu.edu/pc2004g. pdf>.

Wolfe, K. and K. Stubbs. 2015. 2014 Georgia farm gate value report. Univ. Georgia AR-15-01.

Xiao, C.L. and R.J. Boal. 2009. Preharvest application of a boscalid and pyraclostrobin mixture to control postharvest gray mold and blue mold in apples. Plant Dis. 93:185-189. 